\title{
Participation Versus Procedures in Non-Union Dispute Resolution
}

\author{
ALEXANDER J. S. COLVIN \\ Cornell University
}

This study examines the resolution of conflict in non-union workplaces. Employee participation in workplace decision making and organizational dispute resolution procedures are two factors hypothesized to influence the outcomes of conflicts in the non-union workplace. The adoption of high involvement work systems is found to produce an organizational context in which both triggering events for conflict, such as disciplinary and dismissal decisions, and dispute resolution activities, such as grievance filing and appeals, are reduced in frequency. Dispute resolution procedures have mixed impacts. Greater due process protections in dispute resolution procedures in non-union workplaces are associated with increased grievance filing and higher appeal rates but do not have significant impacts on the precursors to conflict. This study provides evidence of substantial organizational level variation in non-union conflict resolution, suggesting the importance of expanding the predominant individual and group-level focus of current conflict management research to include more organizational-level factors. It also supports the importance to non-union employee representation of direct participation strategies involving employee involvement in the workplace, in addition to procedures that provide for off-line representation.

\section{Introduction}

Strategies for providing representation to employees in the non-union workplace commonly fall into one of two different approaches. The first approach is to enhance direct employee participation in workplace decision making through practices like self-directed work teams and employee participation groups. By creating a context in which employees have a greater say in how the workplace is organized and run, this approach is designed to transform the character of employment relations at the point of production and potentially substitute for more indirect forms of representation such as union representation and collective bargaining. The second approach to enhancing non-union employee representation is to establish processes and procedures that provide non-union employees with forms of indirect representation and formal employment protections that parallel those commonly provided by union representation. In this second category would fall practices like nonunion employee representation committees and plans that parallel the representative function of local unions or uniondominated works councils, as well as non-union dispute resolution procedures that parallel the function of union grievance procedures. In this study, I examine the impact of these two alternative approaches in the context of workplace conflict and dispute resolution for non-union employees. Conflict and dispute resolution provide a particularly useful area in which to examine these issues, because they are a key element indicating the nature and character of employment relations in a workplace and also 
implicate both day-to-day relations between managers and workers and the implementation of broader organizational human resource and employment policies.

Conflict is a widespread phenomenon in the workplace. Ranging from quotidian conflicts between employees and supervisors over workplace decisions to major disputes implicating rights to be free from discrimination in employment, conflicts arise regularly in the management of employment relations. These conflicts in turn have impacts on organizations ranging from the disruption of relationships in the workplace and negative impacts on productivity to legal disputes that may expose the organization to significant liability. Organizations, as a consequence, have strong incentives to develop procedures to manage conflict and help resolve disputes that arise in the workplace. In recent years, the incidence of adoption of organizational dispute resolution (ODR) procedures in non-union workplaces has increased, particularly in the United States, and systems for managing workplace conflict have grown in sophistication (Colvin 2003a; Lipsky, Seeber, and Fincher 2003).

The nature of dispute resolution introduces a number of complicating factors in investigating this phenomenon. First, there is a major divide in the United States between dispute resolution in unionized and non-union workplaces, with unionized workplaces almost universally characterized by elaborate grievance arbitration procedures and often intense conflict (Lewin and Peterson 1988), whereas non-union grievance procedures vary widely in their adoption and structure (Colvin 2003a; Colvin, Klaas, and Mahony 2006; Feuille and Chachere 1995). Second, a distinction needs to be made between the effects of the existence versus the usage of dispute resolution procedures and systems (Lewin 1999). For example, whereas the adoption of effective dispute resolution procedures may be positively associated with desirable employment relations outcomes, high levels of usage of these procedures may not have the same positive association. Third, a distinction also needs to be made between indicators of conflict in the workplace, such as employee behaviors leading to disciplinary actions, and indicators of the process of resolution of conflicts, such as grievances filed through dispute resolution procedures. High numbers of grievances may indicate high levels of underlying conflict in the workplace or alternatively a dispute resolution procedure that is effective in giving expression to and then resolving these conflicts. Moving beyond previous research, the present study will incorporate these three distinctions into conceptualizing and examining a range of different aspects of non-union workplace conflict and dispute resolution.

In investigating the impact of the workplace context on conflict and dispute resolution, this study will focus in particular on the phenomenon of high involvement work systems (HIWS). The reason 
for this focus is twofold. First, in the strategic human resource management literature, the use of HIWS by organizations has received particular attention in the investigation of human resource and work organization strategies (Appelbaum et al. 2000; Huselid 1995; MacDuffie 1995), and survey evidence suggests practices associated with HIWS have become increasingly widespread in organizations (Osterman 1994, 2000). Secondly, there are reasons to expect that HIWS will have a particularly strong impact on workplace employment relations including conflict and dispute resolution. Why should we expect a relationship between these two phenomena? Arguments for the adoption of HIWS are premised on the idea that organizations can achieve competitive advantage by better harnessing the human resources of their workforces through promoting high levels of employee commitment and involvement (Becker and Gerhart 1996; Combs et al. 2006; Huselid 1995; Ichniowski et al. 1996). Following the argument, these high levels of commitment and involvement can be obtained by providing employees with the requisite capability, opportunity, and motivation to contribute to the success of the organization through the adoption of policies such as extensive ongoing training, selfmanaged work teams, and performance-based compensation (Appelbaum et al. 2000; Batt 2002; Delery 1998). However, arguments for HIWS are also premised on certain assumptions about the nature of employment relations between management and employees within the organization. If employment relations are characterized by a high degree of conflict between management and employees, it is unlikely that the organization will be able to sustain the high levels of employee involvement and commitment necessary to operation of HIWS (Walton 1985). Conversely, if levels of conflict are low and disputes that arise are efficiently and equitably resolved through ODR systems, this may enhance employee commitment and support HIWS (Cutcher-Gershenfeld 1991).

To summarize, the task in this study is to examine the impacts of organizational context and dispute resolution processes on the resolution of workplace conflict involving non-union employees. The empirical data analyzed in this Participation Versus Procedures in Non-Union Dispute Resolution / 261 study are based on a nationally representative survey of U.S. establishments in the telecommunications industry, which gathered extensive information on various work and employment practices in this industry, including workplace conflict and dispute resolution.

\section{Theory and Literature Review}

A Model of the Resolution of Employment Conflicts in Organizations. Figure 1 presents a conceptual model for understanding how employment conflicts are resolved in organizations. At the center of the model is the idea that there are a set of conflict trigger events that produce disputes in the 
workplace, which are then resolved through a process of dispute resolution activity. So for example, a conflict trigger event might be the imposition of discipline on an employee for misconduct in the workplace. This could then trigger a dispute in which the employee challenged the discipline through filing a grievance, leading to some type of resolution outcome.

\section{FIGURE 1}

\section{A Model of the Resolution of Conflict in Non-Union Workplaces}

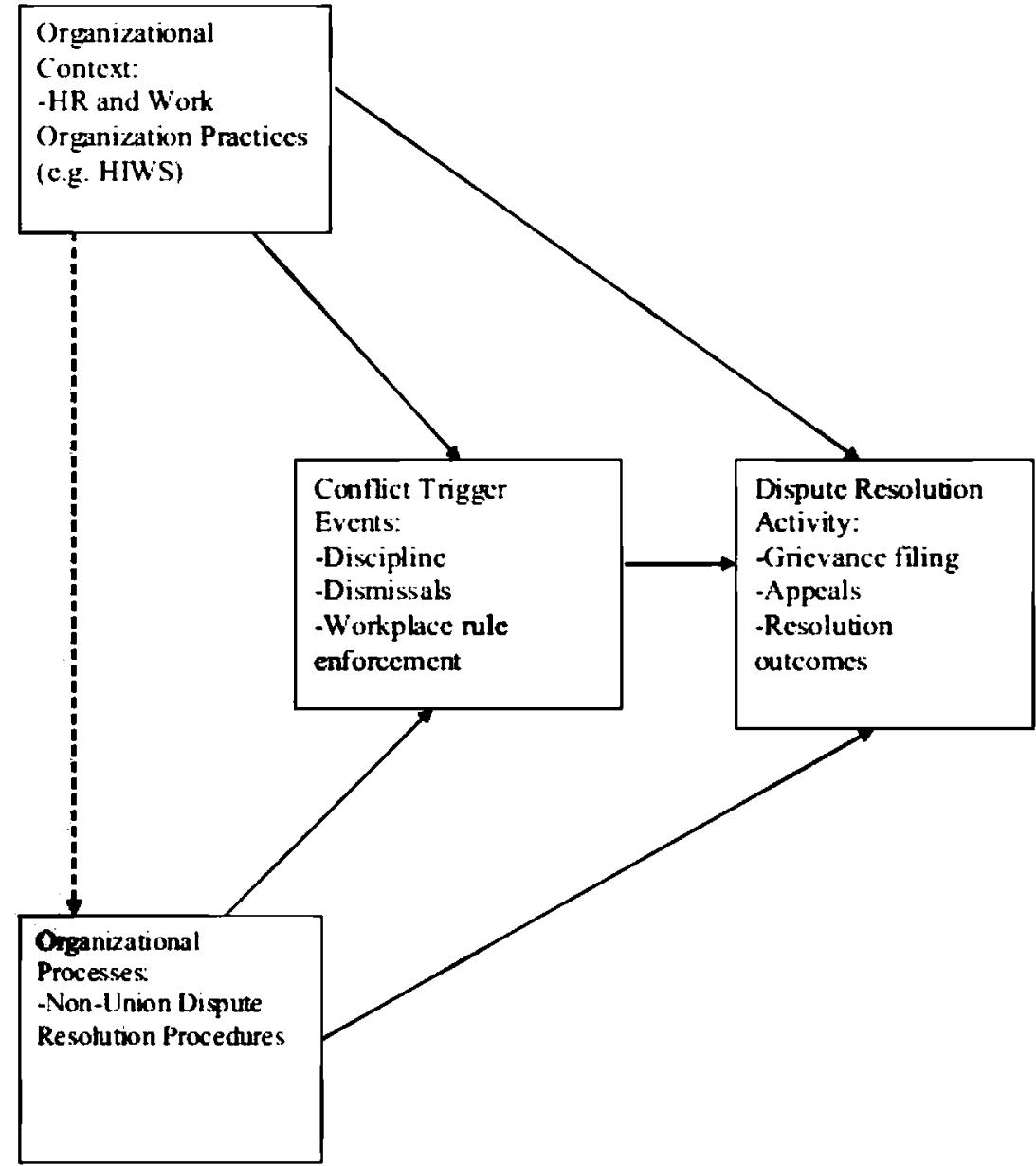

The key idea here is to differentiate between the underlying workplace behavior, which serves as the trigger for conflicts, and the dispute resolution activity, which involves behaviors directed at resolving the conflicts. Each of these two components is affected by two different sets of factors. The first is the organizational context of human resource and work organization practices. For example, if there are 
particularly authoritarian approaches to management of the workforce with a lack of employee participation in decision making, this could have both an effect on conflict trigger events, either producing more of these events or perhaps suppressing them, and on dispute resolution activity, perhaps by discouraging grievance filing by employees. The second set of factors relate to organizational processes. Here the focus in the conflict resolution setting is on the presence and nature of ODR procedures. These procedures will likely have a direct effect on dispute resolution activity but may also have an effect on conflict trigger events, as the potential or lack thereof for review of employee grievances may affect managerial decisions that could trigger a grievance. These two sets of factors, organizational context and processes, represent manifestations in the conflict resolution setting of the two different approaches to non-union employee representation; that is, direct representation through employee participation in decision making in the workplace and indirect representation through procedures that allow expressions of employee voice outside the direct work process. A parallel analogy would be to structures for on-line and off-line employee participation (Appelbaum and Batt 1994). Lastly, organizational context and processes may themselves be related (indicated by the dashed vertical arrow), as organizations with a particular approach to organizing the workplace may be more or less likely to adopt certain dispute resolution procedures.

In the subsequent sections, I examine the various elements of this model.

Process: The Landscape of Organizational Dispute Resolution Procedures. I begin by examining a series of key features of the landscape of dispute resolution in the workplace. Although various terms have been used to describe the areas of alternative dispute resolution, grievance procedures, and conflict management systems, a useful definition of the term "ODR" procedures defines it as "any formal or informal process, identified in organizational policy, as a sanctioned means to resolve disputes within the organization" (Olson-Buchanan and Boswell 2007). There is substantial variation between workplaces in the United States in processes and procedures for resolution of disputes, complaints, or grievances. At one extreme are workplaces where the employees are represented by unions. Unionized workplaces almost universallyfeature multi-step grievance procedures culminating in binding labor arbitration to resolve workplace disputes (Eaton and Keefe 1999). By contrast, dispute resolution procedures in non-union workplaces are characterized by a high degree of variation in incidence and structure (Colvin, Klaas, and Mahony 2006). Many non-union workplaces have no formal procedures in place to resolve employee complaints or grievances. Of those non-union workplaces that do have some type of formal dispute resolution procedure in place, the structures, processes, and systems employed 
vary widely. Some of the most basic procedures simply provide a guideline for to which manager(s) an employee should bring a complaint to seek some form of resolution. More complex procedures may provide for features such as a panel of more senior managers to hear employee grievances. Recent years have seen a growth in more complex non-union ODR procedures. Growing use is being made of nonmanagerial decision makers in procedures such as non-union arbitration procedures and peer review panels, where a form of workplace jury consisting of peers of the employee hears and decides the case (Colvin 2003a). Although adoption of these procedures may be inspired in part by external pressures, such as the threat of union organizing in the case of peer review procedures or as a litigation avoidance technique in the case of non-union arbitration, they nonetheless represent a substantial new element in the management of employment relations in non-union workplaces.

A key issue with non-union ODR procedures is to what degree they incorporate due process protections. Absent due process protections, non-union employees may lack trust in the fairness of ODR procedures and as a result be unwilling to use them. In the unionized setting, the key guarantor of fairness is the provision of a third-party neutral labor arbitrator as the final step decision maker, a feature which is nearly universal in union grievance procedures (Eaton and Keefe 1999; Lewin and Peterson 1988). Conversely for non-union ODR procedures, variation in who is the decision maker and to what degree he or she is independent of management is a major aspect of variation across procedures resulting in different levels of due process protections between procedures. Procedural justice theory suggests that individuals should view procedures with greater due process protections more favorably and hence be more likely to use them (Blancero, DelCampo, and Marron 2010; Thibaut and Walker 1975). Policy-capturing research has found that procedural structure is a major determinant of fairness perceptions (Blancero, DelCampo, and Marron 2010). Previous research on grievance activity in non-union workplaces also found higher grievance rates for non-union ODR procedures that incorporated peer review or arbitration (Colvin 2003b). Overall, existing theory and research suggests that stronger due process protections should lead to higher levels of usage of ODR procedures.

\section{H1: Higher levels of due process protections in non-union organizational} dispute resolution procedures will be associated with greater usage of these procedures.

Two potential corollaries are also suggested by this line of analysis. The first is that employees will have greater success in having disputes resolved in their favor where the procedure has stronger 
due process protections. If due process protections, in particular more independent decision makers, mean less likelihood of the procedure being biased in favor of management, then we would expect employees to win more grievances.

\section{H2: Higher levels of due process protections in non-union organizational} dispute resolution procedures will be associated with higher employee win rates in using these procedures.

The second corollary is that if employees are more likely to be able to successfully use ODR procedures with greater due process protections to challenge unfair management decisions, then this should dissuade managers from making such decisions in the first place. For example, a manager contemplating terminating an employee for misconduct or poor performance is likely to take greater care to ensure that there is a strong justification for the decision if the manager knows that his or her decision may be challenged in front of a peer review panel including rank and file employees rather than simply being reviewed by a fellow manager (Colvin 2004a). The result may be that the presence of a more effective ODR procedure with stronger due process protections reduces the frequency of the type of triggering events in the workplace that produce disputes, such as disciplinary decisions and dismissals.

\section{H3: Higher levels of due process protections in non-union organizational} dispute resolution procedures will be associated with lower levels of conflict triggering events in the workplace.

Context: The Impact of High Involvement Work Systems. I next turn to examine the impact of the context of work and employment relations on workplace dispute resolution, in particular looking at the potential impact of HIWS on ODR procedures and activity.

The starting point for HIWS theory is the idea that organizational performance can be improved by enhancing the commitment and involvement of employees in the workplace (Becker and Gerhart 1996; Combs et al. 2006; Huselid 1995; Ichniowski et al. 1996). To achieve the desired benefits in performance from HIWS, organizations need to adopt a combination of policies directed toward providing employees with the capability, opportunity, and motivation to contribute to the success of the organization (Appelbaum et al. 2000; Bailey 1993; Batt 2002; Delery 1998). Efforts to enhance employee 
capability can include policies and practices such as selecting employees with high skill or education levels and providing employees with extensive ongoing training. Enhancing employee opportunity to contribute can include employee involvement practices such as self-directed work teams and problemsolving groups. Finally, enhancing employee motivation to contribute can involve practices such as performance-based compensation systems linked to key organizational outcomes. Beyond specific practices directed toward enhancing employee commitment, opportunity and motivation to contribute to the organization, HIWS are premised upon a more general strategic orientation concerning how to manage the relationship between employees and the organization (Batt and Colvin 2011). In an important early description of this approach, Walton (1985) drew a contrast between organizations that adopt commitmentbased strategies versus those that adopt "control-based" strategies. Whereas under control-based strategies organizations assume a low trust, high conflict relationship with employees, under commitment-based strategies organizations try to foster a high trust, low conflict relationship with employees (Walton 1985). Thus the commitment-based human resource strategies associated with HIWS are argued to be based in part on development of employee-organization relationships characterized by low levels of conflict.

Past research in the fields of strategic human resource management and industrial relations provides some support for the existence of this relationship between HIWS and low levels of workplace conflict. During the 1980s, industrial relations researchers investigating patterns of transformation of workplace industrial relations identified high grievance rates as a key component of traditional adversarial patterns of workplace relations (Kochan, Katz, and McKersie 1986). A series of studies found associations between adversarial patterns of workplace industrial relations, including high grievance rates, as well as high rates of discipline and absenteeism, and poor organizational performance (Ichniowski 1986; Katz, Kochan, and Gobeille 1983; Katz, Kochan, and Weber 1985; Norsworthy and Zabala 1985). Extending this line of research, Cutcher-Gershenfeld (1991) found that transformed patterns of workplace industrial relations, which were associated with higher productivity, included both less frequent conflicts and faster, more informal resolution of grievances that did arise in the workplace. The strategic human resource management literature also provides some empirical evidence suggesting that there may be a link between HIWS and conflict resolution (Arthur 1992; Huselid 1995). Following Huselid's approach, a series of studies have included access to a formal grievance procedure as one item in scales measuring an employee skills and organizational structure component of HIWS (Datta, Guthie, and Wright 2005; Huselid 1995; Shaw et al. 1998). Similarly, Arthur (1992) included in his cluster analysis of HIWS a "due process" variable measuring the percentage of employee complaints handled through 
formal procedures. In addition, a series of studies of unionized workplaces found associations between patterns of practices related to HIWS and the functioning of grievance procedures (Cutcher-Gershenfeld 1991; Ichniowski 1986; Katz, Kochan, and Weber 1985). More recently, Hoffer-Gittel (2009) conceptualized conflict resolution processes as one element of an HIWS index focusing on practices that promoted relational coordination between employees. These studies suggest a positive relationship between HIWS and ODR procedure adoption and in particular the adoption of procedures with higher levels of due process protections.

Although these studies provide some empirical indication of the existence of an HIWS-conflict resolution relationship, partly motivating the present study, they also used relatively simple measures of conflict resolution procedures and only explored limited aspects of the relationship between HIWS and conflict resolution. More problematically, they generally conceptualize conflict resolution only as a component of HIWS. In practice, organizations may adopt conflict resolution procedures and systems for a range of different motivations, often institutional in nature, such as litigation avoidance or union substitution, as well as to support HIWS (e.g., Colvin 2003a). If procedures are adopted in response to institutional pressures and only partly, if at all, as part of a HIWS strategy, then it may be that the nature and structure of these procedures exert influences on the process of conflict resolution that is separate from and perhaps in opposing directions from those of HIWS. To empirically investigate whether HIWS are associated with the adoption of non-union ODR procedures with stronger due process protections, I test the following hypothesis.

H4: High involvement work systems will be positively associated with the adoption of non-union organizational dispute resolution procedures with higher levels of due process protections.

High Involvement Work Systems and Dispute Resolution Outcomes. In analyzing the impact of ODR procedures it is important to distinguish between the presence and the use of procedures (Lewin 1999; Olson-Buchanan and Boswell 2007). HIWS may be positively associated with the adoption of more complex ODR procedures, as a method of providing due process protections to employees. This could in turn lead to higher levels of dispute resolution activity due to greater willingness of employees to use these procedures to resolve workplace conflicts (Colvin 2003b). However, offsetting this effect, HIWS may affect levels of dispute resolution activity by reducing levels of workplace conflict and thereby 
reduce the number of potential disputes or grievances that could be brought through procedures (Walton 1985). In addition, if more disputes are resolved informally in workplaces with HIWS due to greater trust between managers and employees and more experience with problem solving in the workplace (Cutcher-Gershenfeld 1991), then we would also expect to see fewer disputes having to be resolved through ODR procedures under HIWS. If these latter two effects predominate, then we would expect that among organizations with dispute resolution procedures, HIWS will be associated with lower levels of dispute resolution activity.

\section{H5: High involvement work systems will be associated with fewer} conflict trigger events in the workplace.

H6: High involvement work systems will be associated with lower levels of usage of non-union ODR procedures.

What will be the impact of HIWS on employee likelihood of success in pursuing grievances or complaints through dispute resolution procedures? Here there may again be opposing factors at work (Colvin 2003b). If management is more willing to listen to and respond to employee complaints and concerns under HIWS, then we might expect employee win rates in grievance procedures to be higher with HIWS. On the other hand, if management decision making under HIWS is characterized by greater procedural and distributive fairness, then employee grievances may be considered to have less merit, leading to lower employee win rates under HIWS. Of more concern, it has also been argued that features of HIWS, such as the use of self-managed teams, lead to the elaboration of new forms of discipline and control in which deviation from group norms of involvement and commitment are punished (Barker 1993). Employees filing grievances under HIWS may be viewed as malcontents and the organization less willing to tolerate dissent, leading to lower employee success rates in using procedures. As a result, either greater fairness or greater conformism and less willingness to tolerate dissent under HIWS could result in lower employee win rates. To empirically investigate which effect predominates, I test the following hypothesis based on the second set of arguments.

H7: High involvement work systems will be associated with lower employee win rates in non-union ODR procedures. 


\section{Methods}

Data. The data for this study were collected in a 2003 national survey of establishments in the telecommunications industry. To ensure representativeness, the sample was stratified by size, SIC code, and state location. A university-based survey team administered the survey questionnaire by telephone, which took 52 minutes on average to complete. The individual respondent was the senior manager for the establishment surveyed. After exclusions for missing data on the variables of interest and limiting the investigation to only non-union workplaces, the sample used in this analysis was 261 establishments, corresponding to an effective response rate of 57.9 percent.

Debate over organizational-level survey methods has raised concerns such as overly broad units of analysis and inaccuracies in key informant knowledge. Consistent with suggestions in this literature, establishments (individual workplaces) within a single industry were analyzed in this study to enhance comparability and reduce extraneous sources of variation and measurement error (Becker and Gerhart 1996). To reduce the problem of variation in human resource practices across occupational groups and levels within large organizations, survey questions focused on the "core" workforce of the establishment, defined as the largest group of nonmanagerial employees who perform the primary work function of the establishment. In the telecommunications industry, the core workforce in an establishment consists of either customer service workers or technicians who perform installation and/or repair of equipment. As the data were gathered from a large, nationally representative sample of establishments, it was not feasible to survey multiple respondents at each site. However, as Gerhart et al. (2000) note, establishment-level surveys are generally more reliable than corporate-level surveys as the numbers of employees involved are much smaller and the managers have a very high level of familiarity with the work and employment practices that they are directly responsible for implementing. The average size of the core workforce in the establishments in the sample analyzed was 163 employees and most establishments only had one layer of management between the senior manager and the core workforce employees. More generally, Becker and Huselid (2006) have argued recently that singlerespondent surveys are a reliable method for largescale samples where the respondents are key informants and the measures focus on objective attributes, which is the case for the present study.

Measures; Dispute Resolution Triggers and Activity. As discussed above, one of the dangers in research on ODR is conflating different aspects of dispute resolution, such as structure versus usage of dispute resolution procedures or levels of underlying workplace conflict versus the proportion of such 
conflict resolved through dispute resolution procedures. To address this, multiple measures were used to capture different components of ODR.

The first set of ODR measures provides indicators of the level of conflict trigger events in the workplace. Two variables measured the rate of incidents involving workplace conflict. The dismissal rate is measured as the annual percentage of workers involuntarily dismissed (not including voluntary quits, layoffs, buyouts, or retirements). The discipline rate is measured as the percentage of workers with disciplinary actions recorded against them annually in their personnel records. Discipline and dismissals are focused on here as indicators of the level of workplace conflict because these are commonly major sources of complaints under ODR procedures (Lewin 1999; Lewin and Peterson 1988). In addition to these measures of the aggregate levels of discipline and dismissal in the workplace, a variable was also constructed to capture the willingness of management to punish employees for deviations from organizational rules and norms. This strict workplace rules index was based on the average of the standardized responses to two Likert-scale (low 1-7 high) type questions asking the likelihood that an employee would be dismissed if he or she: "had poor attendance"; or "did not reach work goals."

The second component of ODR to be examined is measures of dispute resolution activity. The most common workplace-level indicator of dispute resolution activity used in past research is the grievance rate, commonly measured as the annual number of grievances filed per 100 employees in the organization (Lewin 1999). A limitation of comparing overall grievance rates, however, is that different dispute resolution procedures may allow different types of complaints to be filed. Many non-union grievance procedures limit the subjects that can be grieved, for example limiting grievances to disciplinary or dismissal issues or excluding grievances challenging company policies and procedures (Colvin 2004a; Feuille and Chachere 1995), whereas union grievance procedures generally allow a broad range of subjects to be grieved based on the extent of the labor contract. To enhance comparability across procedures, the disciplinary grievance rate was measured based on the annual number of grievances concerning discipline or dismissal filed per 100 employees. A second issue in measuring the level of dispute resolution activity is that the grievance rate reflects both the number of incidents of workplace conflict and the rate at which employees use dispute resolution procedures to attempt to resolve these conflicts (Bemmels and Foley 1996). To provide a measure of dispute resolution activity better capturing the likelihood that employees will use a dispute resolution procedure to resolve a given conflict, a measure of the appeal percentage was constructed as the percentage of disciplinary decisions 
appealed through dispute resolution procedures (cf. Colvin 2003b). Lastly, to provide an indicator of employee success in using dispute resolution procedures, the employee win rate was measured as the proportion of disciplinary appeals in which the employee was fully or partly successful.

Dispute Resolution Procedures. To capture the complexity of non-union dispute resolution procedures, an index was constructed based on past researchin this area. A key component in the structure of non-union procedures is who serves as the decision maker under the procedure (Colvin 2003b; Feuille and Chachere 1995). As discussed earlier, in the more basic types of non-union procedures individual managers hear and decide employee grievances. More complexity is introduced under management appeals boards, where multiple decision makers are involved in deciding the grievance, albeit these decision makers are still managers. Greater independence of decision making is achieved through procedures that use nonmanagers as decision makers, including arbitration, mediation, and peer review. A scoring system was constructed based on this classification for who is the decision maker under a non-union grievance procedure: 1 = individual manager at that workplace; 2 = a higherlevel manager; 3 = management appeals boards; 4 = peer review panel; 5 = outside neutral arbitrator or mediator. This classification of procedures based on the nature of the decision makers follows a similar approach to an index developed by Feuille and Chachere (1995). It is also supported by Colvin's (2003b) finding of significant differences in usage between non-union grievance procedures with nonmanagerial decision makers, in that instance arbitration and peer review, and procedures with only managerial decision makers. Many non-union dispute resolution procedures include multiple steps, with different types of decision makers involved at each step of the procedure (Lewin 1987). In companies that provide procedures with multiple steps and different types of resolution processes at each step, the combined effect can be to allow employees more effective opportunities to obtain review of grievances (Colvin 2004a). To capture both the effect of different types of decision makers and of having multiple steps in procedures, I constructed a due process index that summed the scores described above based on type of decision maker for each step in the procedure. This index was standardized to enhance comparability with the similarly standardized HIWS index used in the analysis.

High Involvement Work Systems. To capture the incidence of HIWS I constructed a measure based on an index developed by Batt (2002) in an earlier study of human resource practices in the telecommunications industry. As discussed above, past research has argued that to establish HIWS, organizations need to adopt combinations of policies directed toward providing employees with the 
capability, opportunity, and motivation to contributed to the success of the organization (Appelbaum et al. 2000; Bailey 1993; Batt 2002; Delery 1998). Drawing on this framework, Batt (2002) constructed an additive HIWS index capturing three components: skill level, work design, and involvement-enhancing HR incentives. Although other HIWS indexes have been proposed in the literature (e.g., Arthur 1994; Huselid 1995; MacDuffie 1995), the index constructed by Batt (2002) has the advantage for use in the present study of being developed in the same industry and incorporating important industry-specific practices (for example, the important role of electronic monitoring of employees in the telecommunications industry).

A combination of indicators based on the set of items developed by Batt (2002) was used to capture each of the three components of the HIWS index. Employee skill levels were captured by a variable additively combining standardized measures of: the average years of education of new hires, and the numbers of weeks of formal and on-the-job training required for new employees to achieve job proficiency. Work design was captured by additively combining standardized measures of the percentage of the core workforce participating in off-line problem-solving groups, the percentage of the core workforce participating in on-line self-managed work teams, and an eight-question scale capturing worker autonomy in workplace decision making. Involvement-enhancing HR incentives were captured by additively combining standardized measures of the percentage of core workers who are full-time, permanent employees, the natural log of average pay of core employees, the percentage of working time that is electronically monitored (reverse coded), and the number of days of ongoing training provided to employees annually. One practice often used as a component of employee motivation in HIWS indexes that was not included here is performance-based pay. The reason for excluding it in this study is that in the telecommunication industry setting examined here, performance-based pay almost entirely consists of commission-based pay for sales employees. As a result, it serves a different function in telecommunications than the types of performancebased pay, such as gainsharing for contributions to organizational performance, commonly described in the HIWS literature. An overall HIWS index was then calculated as the standardized sum of the standardized measures of employee capability, employee opportunity, and employee motivation. This methodology of constructing an additive HIWS index is also similar to the approach used in a recently study by Wright et al. (2005). To test an alternative approach, we calculated a multiplicative HIWS index to see if this suggested different effects (cf. MacDuffie 1995). Results for the multiplicative index were similar to those for the additive index for the relationships examined in this study, so for reasons of parsimony and consistency with past research the analysis and results presented here are based on use of the additive HIWS index. 
Control Variables. Several measures describing other characteristics of the establishment and workforce are included as control variables in the analysis. A dichotomous variable, customer service workers, captures the two major occupational groups in the industry $(1=$ customer service workers; $0=$ technicians). Dichotomous variables capture two organizational characteristics that might affect how workplace conflicts are handled: whether this workplace was a branch of a larger organization $(1=$ branch; $0=$ not a branch); and whether there was an HR office in the workplace $(1=$ yes; $0=$ no $)$. Another dichotomous variable captures whether or not the core workforce is classified as exempt from wage and hour laws $(1=$ exempt; $0=$ nonexempt). Workforce size is measured as the natural log of the total number of employees in the establishment. Another characteristic of the workforce included as a control variable is the percentage of the workforce that is female.

\section{Results}

Descriptive statistics and correlations for the variables used in this study are reported in Table 1. Tables 2 and 3 report regression results for the dependent variables being examined. A number of the ODR measures analyzed here have truncated distributions, where there is an upper or lower limit to the possible range of observed outcomes. For example, the distributions of discipline, dismissal, and grievance rates have lower limits of zeros, as it is impossible to have negative rates. There can also be a number of observations at the lower limit of zero for each of these types of rates. Ordinary least squares regression coefficient estimates for truncated distributions are biased upwards (Long 1997). Tobit regression models correct for this problem, providing unbiased estimates of the coefficients. As a result, tobit models with lower limits are used for estimation of the equations for the following dependent variables: discipline rate, dismissal rate, disciplinary grievance rate, discipline appeal proportion, and employee win rate. OLS is used for estimation of the due process index and strict rules index equations.

The first question examined in the analysis is whether there is a link between HIWS and the due process index. The first model in Table 2 examines this issue by testing whether the HIWS index is a significant predictor in a model with the due process index as the dependent variable. The results do not indicate any significant association between the HIWS index and the due process index. Thus hypothesis H4 was not supported. However, this failure to find a significant relationship between HIWS and the due process index provides some support for the decision in the model to treat the organization context and process factors as separate constructs, rather than just viewing dispute resolution procedures as a component of HIWS. 
TABLE /

Means, Standard Deviations, and Correlatrons for Varuables

\begin{tabular}{|c|c|c|c|c|c|c|c|c|c|c|c|c|c|c|c|c|c|}
\hline & Variable & Mean & $S D$ & 1 & 2 & 3 & 4 & 5 & 6 & 7 & 8 & 9 & 10 & 11 & 12 & 13 & 14 \\
\hline 1 & $\begin{array}{l}\text { High involvement work } \\
\text { systems index }\end{array}$ & 0.15 & 0.74 & 1 & & & & & & & & & & & & & \\
\hline 2 & Due process index & 0.03 & 1.01 & -0.01 & 1 & & & & & & & & & & & & \\
\hline 3 & Discipline rate & 14.08 & 21.40 & -0.31 & 0.06 & 1 & & & & & & & & & & & \\
\hline 4 & Dismissal rate & 6.78 & 9.98 & -0.27 & 0.04 & 0.28 & 1 & & & & & & & & & & \\
\hline 5 & Strict workplace rules & -0.04 & 0.83 & -0.12 & 0.05 & 0.03 & 0.17 & 1 & & & & & & & & & \\
\hline 6 & Grievanoe rate (In) & 0.43 & 0.84 & -0.18 & 0.11 & 0.05 & 0.21 & 0.09 & 1 & & & & & & & & \\
\hline 7 & Appeal percentage & 6.87 & 16.59 & -0.13 & 0.07 & -0.02 & 0.13 & 0.09 & 0.87 & 1 & & & & & & & \\
\hline 8 & Employee win rate & 4.67 & 17.94 & -0.18 & 0.04 & 0.19 & 0.18 & 0.03 & 0.30 & 0.20 & 1 & & & & & & \\
\hline 9 & $\begin{array}{l}\text { Customer service } \\
\text { workers }\end{array}$ & 0.55 & 0.50 & -0.16 & 0.03 & 0.16 & 0.18 & 0.04 & 0.06 & 0.01 & 0.17 & 1 & & & & & \\
\hline 10 & Branch of larger org. & 0.74 & 0.44 & -0.19 & -0.06 & 0.08 & 0.13 & 0.03 & 0.00 & -0.05 & 0.09 & 0.01 & 1 & & & & \\
\hline 11 & HR office in workplace & 0.50 & 0.50 & -0.16 & 0.06 & -0.11 & 0.10 & 0.09 & -0.05 & -0.04 & 0.05 & 0.13 & 0.06 & 1 & & & \\
\hline 12 & Workforce size (In) & 3.72 & 1.38 & -0.41 & -0.04 & 0.16 & 0.22 & 0.15 & 0.12 & 0.09 & 0.20 & 0.38 & 0.15 & 0.33 & 1 & & \\
\hline 13 & Female employees & 0.40 & 0.35 & -0.30 & 0.07 & 0.09 & 0.05 & 0.03 & 0.06 & 0.05 & 0.09 & 0.62 & 0.00 & 0.12 & 0.26 & 1 & \\
\hline 14 & Exempt workforce & 0.25 & 0.44 & 0.31 & 0.00 & 0.02 & 0.06 & 0.06 & 0.03 & 0.00 & 0.07 & 0.05 & 0.03 & -0.02 & -0.08 & -0.08 & 1 \\
\hline
\end{tabular}

TABLE 2

Results of Regressions of HiWS on Due Process Index and Conflict Trigcer Events

\begin{tabular}{|c|c|c|c|c|}
\hline Variable & $\begin{array}{c}\text { (1) } \\
\text { Due Process } \\
\text { Index (non-union) } \\
\text { (OLS) }\end{array}$ & $\begin{array}{l}\text { (2) } \\
\text { Discipline } \\
\text { rate (Tobit) }\end{array}$ & $\begin{array}{l}\text { (3) } \\
\text { Dismissal } \\
\text { rate (Tobit) }\end{array}$ & $\begin{array}{c}(4) \\
\text { Strict } \\
\text { workplace } \\
\text { nuks (OLS) }\end{array}$ \\
\hline \multicolumn{5}{|l|}{ Context } \\
\hline HIWS index & $-0.03(0.10)$ & $-15.04^{* * * *}(2.45)$ & $-8.09^{* * *}(1.56)$ & $-0.12(0.08)$ \\
\hline \multicolumn{5}{|l|}{ Processes } \\
\hline Due process index & & $2.35(1.47)$ & $1.31(0.94)$ & $0.04(0.05)$ \\
\hline \multicolumn{5}{|l|}{ Controls } \\
\hline Customer service workers & $-0.01(0.17)$ & $5.97(4.05)$ & $6.90^{* *}(2.58)$ & $-0.04(0.14)$ \\
\hline Branch of larger organization & $-0.14(0.15)$ & $3.02(3.47)$ & $2.66(2.24)$ & $-0.01(0.12)$ \\
\hline HR office in workplace & $0.16(0.13)$ & $-7.68 *(3.10)$ & $2.36(1.98)$ & $0.06(0.11)$ \\
\hline Workforce size (log) & $-0.06(0.06)$ & $1.07(1.29)$ & $1.03(0.81)$ & $0.07(0.05)$ \\
\hline Female employees (\%) & $0.24(0.24)$ & $-5.39(5.55)$ & $-10.05^{* *}(3.65)$ & $-0.04(0.19)$ \\
\hline Exempt workforce & $0.02(0.15)$ & $7.70 *(3.61)$ & $3.49(2.30)$ & $0.20(0.13)$ \\
\hline Constant & $0.20(0.23)$ & $7.20(5.40)$ & $-4.78(3.48)$ & $-0.32+(0.19)$ \\
\hline \multirow[t]{2}{*}{ LRDChisq $[F]$} & 0.68 & $60.14^{*+*}$ & $61.49 * * *$ & 135 \\
\hline & 0.018 & 1956.54 & 1350.61 & 0,041 \\
\hline \multicolumn{5}{|l|}{$-2 \times$ Log likelihood $\left[R^{2}\right]$} \\
\hline Observations & 261 & 261 & 261 & 261 \\
\hline
\end{tabular}

Table 2 also reports results of regressions of the HIWS index, the due process index, and control variables on workplace conflict measures. The second, third, and fourth models in Table 2 each report results for different measures of workplace conflict. In model 2, the HIWS index has a significant negative association with the discipline rate $(\mathrm{p}<0.001)$, supporting hypothesis $\mathrm{H} 5$. To calculate effect sizes for the change in the expected value of the dependent variable for a given change in an 
independent variable in the model, it is necessary to make a conversion calculation from the Tobit coefficients, which are parameters for the unobserved latent variable (Long 1997). Effect sizes reported here for Tobit models are based on calculations of the marginal effect on the expected value of the outcome variable. A one standard deviation increase in the HIWS index is associated with a 6.40 percentage point reduction in the discipline rate. By contrast, the due process index is not significantly associated with the discipline rate in model 2 , in contrast to the prediction in hypothesis $\mathrm{H} 3$. In model 3 , the HIWS index has a significant negative association with the dismissal rate $(p<0.001)$, again supporting hypothesis H5. A one standard deviation increase in the HIWS index is associated with a 2.25 percentage point reduction in the dismissal rate. By contrast again, the due process index does not have a significant association with the dismissal rate in model 3, failing to provide support for hypothesis $\mathrm{H} 3$. Lastly, in model 4, neither the HIWS index nor the due process index have significant associations with the strictness of workplace rules $(p<0.10)$.

TABLE 3

Results of Regressions of Due Process Index and HIWS Index on Conflict Resolution ACTIVITY

\begin{tabular}{|c|c|c|c|}
\hline Variable & $\begin{array}{l}\text { (1) } \\
\text { Grievance } \\
\text { rate (Tobit) }\end{array}$ & $\begin{array}{c}(2) \\
\text { Appeal } \\
\text { percentage (Tobit) }\end{array}$ & $\begin{array}{l}\text { (3) } \\
\text { Employe win } \\
\text { rate (Tobit) }\end{array}$ \\
\hline \multicolumn{4}{|l|}{ Context } \\
\hline HIWS index & $-1.38^{* * *}(0.40)$ & $-24.86^{* *}(7.65)$ & $-55.42 *(21.71)$ \\
\hline \multicolumn{4}{|l|}{ Processes } \\
\hline Due process index & $0.71 *(0.28)$ & $12.17^{*}(5.37)$ & $14.66(15.19)$ \\
\hline \multicolumn{4}{|l|}{ Controls } \\
\hline Customer service workers & $0.36(0.66)$ & $2.06(12.64)$ & $61.69+(35.99)$ \\
\hline Branch of larger organization & $-0.16(0.53)$ & $-6.11(10.06)$ & $52.57(37.95)$ \\
\hline HR office in workplace & $-0.42(0.47)$ & $-7.49(8.94)$ & $3.36(23.52)$ \\
\hline Workfore size (log) & $0.12(0.17)$ & $2.88(3.24)$ & $9.45(7.77)$ \\
\hline Female employees $(\%)$ & $-0.20(0.90)$ & $0.19(17.16)$ & $-57.38(50.12)$ \\
\hline Exempt workforce & $0.44(0.54)$ & $7.07(10.25)$ & $24.34(25.53))(-1)$ \\
\hline Constant & $-2.07 *(0.87)$ & $-39.39^{*}(16.39)$ & $-216.63^{* 4 *}(64.14)$ \\
\hline Likclihood-ratio chi-square & $\begin{array}{r}26.22 * *+ \\
313.71\end{array}$ & $\begin{array}{r}23.77^{* *} \\
592.53\end{array}$ & $\begin{array}{r}26.95 * * * \\
275.78\end{array}$ \\
\hline \multicolumn{4}{|l|}{$-2 \times$ Log likelihood } \\
\hline Observations & 180 & 180 & 180 \\
\hline
\end{tabular}

The three models in Table 3 report results for measures of ODR activity. For this part of the analysis, only those non-union workplaces that had some type of formal dispute resolution procedure ( $\mathrm{n}$ $=180$ ) were included as measures like a grievance rate become meaningless in the absence of a grievance procedure. The grievance rate, the dependent variable in the first model in Table 3, provides a measure of overall levels of dispute resolution activity. The results reported in model 1 in Table 2 
indicate a significant negative association between the HIWS index and the log of the disciplinary grievance rate $(p<0.001)$, supporting hypothesis H6. A one standard deviation increase in the HIWS index is associated with a 28.3 percent reduction in the disciplinary grievance rate. The results in model 1 also indicate that the due process index has a significant positive association $(p<0.05)$ with the disciplinary grievance rate, supporting hypothesis $\mathrm{H} 1$. A one standard deviation increase in the due process index is associated with an 18.5 percent increase in the disciplinary grievance rate. Whereas the grievance rate is influenced by both the underlying level of conflict and the willingness of employees to use the ODR procedures, the activity measure analyzed in model 2 inTable 3 , the appeal proportion, measures the likelihood of using the ODR procedures for a given conflict. However, similar to the results for the grievance rate, there is a significant negative association between the HIWS index and the disciplinary appeal proportion ( $<<0.01$, model 2 , Table 3 ), supporting hypothesis $\mathrm{H} 6$. A one standard deviation increase in the HIWS index is associated with a 5.68 percentage point reduction in the disciplinary appeal proportion. This indicates that the effect of HIWS on dispute resolution activity is not simply a product of a conflict reduction effect, but rather lower usage of procedures for a given set of disputes. The results in model 2 also indicate that the due process index has a significant positive association with the appeal proportion $(\mathrm{p}<0.05)$, supporting hypothesis $\mathrm{H} 1$. A one standard deviation increase in the due process index is associated with a 2.78 percentage point increase in the disciplinary appeal proportion. Lastly, how successful are employees in using procedures? Results reported in model 3 in Table 3 indicate a significant negative association between the HIWS index and employee win rates $(\mathrm{p}<0.05)$ in disciplinary grievance rates, supporting hypothesis $\mathrm{H} 7$. A one standard deviation increase in the HIWS index is associated with a 3.15 percentage point reduction in the employee win rate. It should be noted, however, that the comparison of win rates does not control for differences in the quality of grievances brought by employees, so the result could be interpreted as indicating either a dispute resolution procedure that is less favorable for employees, or a combination of less valid employee complaints and/or better justified management disciplinary decisions. By contrast, the due process index does not have a significant association with the employee win rate in model 3.

What do these results say about the relative impact of context and process factors on workplace conflict and dispute resolution? The HIWS index had consistent significant associations with both workplace conflict and dispute resolution outcomes. Higher levels of employee involvement were associated with less workplace conflict and lower rates of dispute resolution activity. This suggests 
that HIWS are an important factor in predicting outcomes in non-union workplaces. By contrast, the due process index was not a significant predictor of workplace conflict levels. However, higher scores on the due process index were significantly associated with higher rates of dispute resolution activity.

This suggests that variation in dispute resolution procedures is a factor affecting resolution of disputes. We can make a rough comparison of the relative magnitude of the effects on dispute resolution activity as both the HIWS index and the due process index are standardized measures. The absolute magnitudes of the coefficients on the HIWS index are approximately twice as large as the absolute magnitude of the coefficients on the due process index in the models for the grievance rate and the appeal percentage. The magnitude of the impact of contextual factors appears to be greater than that of process factors by these measures.

\section{Discussion}

The results presented here support the existence of a set of relationships between HIWS and both workplace conflict and dispute resolution activity. Beginning with workplace conflict, HIWS are premised on the idea that organizations can improve the performance of their workforces by fostering high levels of employee involvement and commitment (Batt and Colvin 2011; Becker and Gerhart 1996; Huselid 1995; Ichniowski et al. 1996). High levels of conflict in the workforce can threaten the ability to sustain this involvement and commitment, so organizations adopting HIWS have a strong incentive to make efforts to reduce workplace conflict (Walton 1985). Conversely, to the degree that HIWS enhance trust and commitment in the workplace, this should reduce conflict levels. The results of this study provide strong support for an association between HIWS and lower levels of workplace conflict.

When we turn to the relationship between HIWS and dispute resolution activity, the interpretation of the relationships is more ambiguous. The conflict reduction effect of HIWS, described earlier, should lead to an overall reduction in the number of disputes in the workplace. This should be manifested in reduced grievance rates in workplaces with HIWS (Colvin 2003b, 2004b). This prediction is supported by the results of this study, which show a strong negative relationship between HIWS and grievance rates. However, the impact of HIWS on the proportion of conflicts that result in grievances being brought by employees through a dispute resolution procedure is less clear. It may be that there is a greater trust in the effectiveness of procedures under HIWS. Past research has shown that retaliation against complainants is a common weakness of workplace dispute resolution procedures (Lewin 1999). To the degree that employees under HIWS have greater trust that management will not engage in retaliation, they should be more likely to file a grievance through a procedure to resolve a conflict. On 
the other hand, if HIWS result in employees perceiving greater procedural and distributive fairness in management decision making and more willingness to resolve problems informally (Cutcher-

Gershenfeld 1991), then this may reduce the perceived need to useThe results of this study indicate that the proportion of conflicts, in this case disciplinary decisions that lead to employees filing grievances, is lower under HIWS. The results do not allow us to distinguish between whether employees are filing a lower proportion of grievances because they are more accepting of the fairness of management decisions or because they are afraid of being perceived as not being a "team player" under the HIWS if they file grievances. Which of these explanations is behind this finding is an important question for future research to address. A dispute resolution procedures to resolve conflicts. More negatively, employees may also feel under HIWS that filing grievances under dispute resolution procedures will be viewed as indicating that the employee lacks trust and commitment toward the organization and hence has attitudes incompatible with the HIWS environment that management is seeking to foster in the workplace.

One result that does raise potential concerns about the impact of HIWS on dispute resolution activity is the finding of a lower employee win rate in grievance procedures under HIWS. Here again, however, there are similar alternative interpretations. Management may be more resistant to accepting employee grievances under HIWS out of an assumption that employees should be displaying greater trust and commitment and that grievance filing is an indicator that the employee is not a team player under the HIWS. However, it could also be that the quality or validity of grievances filed is lower where there is a HIWS. If management decisions are generally more procedurally and distributively just under HIWS, then the number of valid grievances will be lower. In addition, if HIWS lead to employees and managers resolving many problems informally in the workplace, then this could result in the remaining unresolved conflicts being those in which the employees' complaints are less valid. Future research could valuably investigate the reasons for the finding of lower employee success rates in grievances under HIWS, which may have implications for the nature of employment relations under these systems.

The results of this study also provide support for the importance of the structure of dispute resolution procedures for dispute resolution activity in the nonunion workplace. Procedures that feature higher due process protections through more independent decision makers and more opportunities for appeal and review of decisions tend to be used more by employees. To the degree that employees are effectively expressing their preferences through their behavior, the greater willingness to use these procedures suggests that more extensive due process protections are an attractive feature of procedures for employees. The results did not indicate a greater employee win rate for grievances 
brought through procedures with more extensive due process protections. Although that might initially suggest that these procedures do not provide any enhancement of employee prospects of success in grievances, it is important to consider the impact of due process protections on the type of grievances being brought. Procedures lacking in due process protections may discourage employees from bringing forward all but the strongest grievances with the greatest probabilities of success (Colvin 2003b). If a fairer procedure were to increase the probability of succeeding with a given grievance that could increase the incentive to filegrievances with less clear-cut evidence or more marginal prospects of success. Thus the win rate could stay relatively constant even as the prospects for success on any given grievance increase due to the expanding and changing pool of grievances being filed. This would be an analogue in the ODR setting to the Priest-Klein hypothesis observed in litigation where win rates tend to regress toward an even distribution of wins and losses as particularly stronger cases are settled out and weak cases are abandoned (Priest and Klein 1984).

The results did not provide support for an impact of procedures with stronger due process protections on the level of conflict trigger events in the workplace. It could have been that stronger procedures would have discouraged managers from taking the types of disciplinary or dismissal decisions that could lead to grievances. In this respect, non-union procedures appear to be more reactive devices, rather than serving a preventative function toward conflict. At the same time, from a managerial perspective this might be seen as an encouraging finding in that these procedures do not appear to inhibit management decision making in the workplace. However, it should also be noted that this study focused specifically on procedures for resolving disputes that have already arisen. Research suggests that some organizations have adopted more proactive systems designed to help prevent conflict from arising in the workplace (Lipsky, Seeber, and Fincher 2003). These types of conflict management systems could have an effect of reducing the rate of conflict trigger events in the workplace, which would not necessarily be captured by the procedure measures used in this study.

Some other limitations of this study should also be recognized. It is based on a study of a single industry and so additional research would be valuable to determine the generalizability of the results. The data are drawn from a cross-sectional survey, limiting the ability to draw causal inferences. Although it seems more likely that HIWS influence workplace conflict and dispute resolution, it could be that in some instances causality runs in the reverse direction. For example, endemic high levels of conflict in the workplace may inhibit an organization from successfully operating a HIWS, leading to its abandonment in favor of a more directive, control-oriented approach to management. Lastly, although a number of different ODR measures are examined in this study, ODR systems are complex phenomena 
and there are other aspects of them that could be investigated (see e.g., Bendersky 2003; Constantino and Merchant 1996; Lipsky, Seeber, and Fincher 2003).

\section{Conclusion}

The question of how to provide effective representation to non-union employees is a central issue for employment relations in an era of declining unionization. Workplace dispute resolution is one of the key areas that need to be addressed in thinking about non-union employee representation. If employees are unable to effectively challenge unfair management decisions then they are in essence supplicants rather than citizens of the organization. From this perspective, the right to petition for redress is as much a part of organizational citizenship as it is of political citizenship.

In thinking about policies from promoting non-union employee representation, the results of this study indicate the importance of focusing on the work and employment systems context, rather than just formal procedures for representation. The results presented here indicate that the system of work organization adopted by the organization can have a greater impact on important outcomes like levels of conflict in the workplace and the outcome of resolution of employee grievances than do formal procedures designed to provide nonunion employees with representation and rights protection. This suggests that we should think of strategies such as encouraging work and employment systems that enhance direct employee participation in workplace decision making not just from the perspective of how they impact performance-related outcomes, but also from the perspective of how they can enhance representation of employee interests in dispute resolution. Procedures are not unimportant and the results presented here indicate that they do affect workplace dispute resolution activity. However, if we consider the relative role of direct participation versus that of procedures, the results of this study indicate that it is participation that matters most. 


\section{REFERENCES}

Appelbaum, Eileen, and Rosemary Batt. 1994. The New American Workplace: Transforming Work Systems in the United States. Ithaca, NY: Cornell University Press.

-- , Thomas Bailey, Peter Berg, and Arne Kalleberg. 2000. Manufacturing Advantage. Ithaca, NY: Cornell University Press.

Arthur, Jeffrey. 1992. "The Link Between Business Strategy and Industrial Relations Systems in American Steel Minimills." Industrial and Labour Relations Review 45: 488-506.

- - . 1994. "Effects of Human Resource Systems on Manufacturing Performance and Turnover." Academy Management Journal 37(3): 670-87.

Bailey, Thomas. 1993. Discretionary Effort and the Organization of Work: Employee Participation and Work Reform since Hawthorn. New York: Columbia University.

Barker, James R. 1993. "Tightening the Iron Cage: Concertive Control in Self-Managing Teams." Administrative Science Quarterly 38(3): 408-37.

Batt, Rosemary. 2002. "Managing Customer Services: Human Resource Practices, Quit Rates, and Sales Growth." Academy Management Journal 45(3): 587-97.

- - - and Alexander J. S. Colvin. 2011. "An Employment Systems Approach to Turnover: HR Practices, Quits, Dismissals, and Customer Satisfaction." Academy of Management Journal 54(4): 695-717. Forthcoming.

Becker, Brian E., and Barry Gerhart. 1996. "Special Research Forum: Human Resource Management and Organizational Performance." Academy Management Journal 39(4): 777-985.

---, and Mark A. Huselid. 2006. "Strategic Human Resources Management: Where Do We Go from Here?" Journal of Management 32(6): 898-925.

Bemmels, Brian, and Janice R. Foley. 1996. "Grievance Procedure Research: A Review and Theoretical Recommendations." Journal of Management 22(3): 359-84.

Bendersky, Corinne. 2003. "Organizational Dispute Resolution Systems: A Complementarities Model." Academy of Management Review 28(4): 643-56.

Blancero, Donna Maria, Robert G. DelCampo, and George F. Marron. 2010. "Just Tell Me! Making Alternative Dispute Resolution Systems Fair." Industrial Relations 49(4): 524-43.

Colvin, Alexander J. S. 2003a. "Institutional Pressures, Human Resource Strategies, and the Rise of Nonunion Dispute Resolution Procedures." Industrial and Labour Relations Review 56(3): 375-92.

- - . 2003b. "The Dual Transformation of Workplace Dispute Resolution." Industrial Relations 42(4): 
712-35.

- - . 2004a. "Adoption and Use of Dispute Resolution Procedures in the Nonunion Workplace." Advances in Industrial Labour Relations 13: 69-95.

- - . 2004b. "The Relationship between Employee Involvement and Workplace Dispute Resolution." Relational Industrielles 59(4): 671-94.

- - , Brian Klaas, and Douglas Mahony. 2006. "Alternative Dispute Resolution." In Contemporary Issues in Employment Relations, edited by D. Lewin, pp. 103-47. Ithaca, NY: ILR Press.

Combs, James, Yongmei Liu, Angela Hall, and David Ketchen. 2006. "How Much Do High-Performance Work Practices Matter? A Meta-Analysis of Their Effects on Organizational Performance." Personnel Psychology 59: 501-28.

Constantino, Cathy A., and Christina S. Merchant. 1996. Designing Conflict Management Systems: A Guide to Creating Productive and Healthy Organizations. San Francisco, CA: Jossey-Bass.

Cutcher-Gershenfeld, Joel. 1991. "The Impact on Economic Performance of a Transformation in Workplace Relations." Industrial and Labour Relations Review 44(2): 241-60.

Datta, Deepak K., James P. Guthie, and Patrick M. Wright. 2005. "Human Resource Management and Labor Productivity: Does Industry Matter?" Academy Management Journal 48: 135-46.

Delery, John. 1998. "Issues of Fit in Strategic Human Resource Management: Implications for Research." Human Resource Management Review 8(3): 289-309.

Eaton, Adrienne E., and Jeffrey H. Keefe 1999. "Introduction and Overview." In Employment Dispute Resolution and Worker Rights in the Changing Workplace, edited by A. Eaton and J. Keefe, pp. 1-26. Champaign, IL: Industrial Relations Research Association.

Feuille, Peter, and Denise R. Chachere. 1995. "Looking Fair or Being Fair: Remedial Voice Procedures in Nonunion Workplaces." Journal of Management 21: 27-42.

Gerhart, Barry, Patrick M. Wright, Gary C. McMahan, and Scott Snell. 2000. “Measurement Error in Research on the Human Resources and Firm Performance Relationship: How Much Error Is There and How Does it Influence Effect Size Estimates?" Personnel Psychology 53(4): 803-34.

Hoffer-Gittel, Jody. 2009. High Performance Healthcare: Using the Power of Relationships to Achieve Quality, Efficiency and Resilience. New York, NY: McGraw-Hill Professional.

Huselid, Mark A. 1995. "The Impact of Human Resource Management Practices on Turnover, Productivity, and Corporate Financial Performance." Academy Management Journal 38: 635-72.

Ichniowski, Casey. 1986. "The Effects of Grievance Activity on Productivity." Industrial and Labour Relations Review 40(1): 75-89.

- - , Thomas A. Kochan, David Levine, Craig Olson, and George Strauss. 1996. "What Works at Work: 
Overview and Assessment." Industrial Relations 35(3): 356-74.

Katz, H., T. Kochan, and K. Gobeille. 1983. "Industrial Relations Performance, Economic Performance, and QWL Programs: An Interplant Analysis." Industrial and Labour Relations Review 37(1): 3-17.

- - , - - , and M. Weber. 1985. "Assessing the Effects of Industrial Relations and Quality of Work Life Efforts on Organizational Effectiveness." Academy Management Journal 28(3): 509-27.

Kochan, T., H. Katz, and R. McKersie. 1986. The Transformation of American Industrial Relations. New York, NY: Basic Books.

Lewin, David. 1987. "Dispute Resolution in the Nonunion Firm: A Theoretical and Empirical Analysis." Journal of Conflict Resolution 31(3): 465-502.

- - , 1999. "Theoretical and Empirical Research on the Grievance Procedure and Arbitration: A Critical Review." In Employment Dispute Resolution and Worker Rights, edited by A. Eaton and J. Keefe, pp. 137-86. Champaign, IL: Industrial Relations Research Association.

- - , and R. Peterson. 1988. The Modern Grievance Procedure in the United States: A Theoretical and Empirical Analysis. Westport, CT: Quorum.

Lipsky, David B., Ronald L. Seeber, and Richard D. Fincher. 2003. Emerging Systems for Managing Workplace Conflict. San Francisco, CA: Jossey-Bass.

Long, J. Scott. 1997. Regression Models for Categorical and Limited Dependent Variables. Thousand Oaks, CA: Sage.

MacDuffie, John-Paul. 1995. "Human Resource Bundles and Manufacturing Performance: Organizational Logic and Flexible Production Systems in the World Auto Industry." Industrial and Labour Relations Review 48: 197-221.

Norsworthy, J. A., and Craig A. Zabala. 1985. "Worker Attitudes, Worker Behavior, and Productivity in the U.S. Automobile Industry, 1959-76." Industrial and Labour Relations Review 38(4): 544-57.

Olson-Buchanan, Julie, and Wendy R. Boswell. 2007. "Organizational Dispute Resolution Systems." In The Psychology of Conflict and Conflict Management in Organizations, edited by Carsten K. W. De Drue and Michele J. Gelfand. New York, NY: SIOP Frontiers Series, Erlbaum.

Osterman, Paul. 1994. "How Common Is Workplace Transformation and Who Adopts It?" Industrial and Labour Relations Review 47: 173-88.

- - . 2000. "Work Reorganization in an Era of Restructuring: Trends in Diffusion and Effects on Employee Welfare." Industrial and Labour Relations Review 53: 179-96.

Priest, George L., and Benjamin Klein. 1984. "The Selection of Disputes for Litigation.” Journal of Legal Studies 1: 1-55.

Shaw, Jason, John Delery, G. Douglas Jenkins Jr, and Nina Gupta. 1998. "An Organization-Level Analysis of Voluntary and Involuntary Turnover." Academy Management Journal 39(5): 1-15. 
Thibaut, John W., and Laurens Walker. 1975. Procedural Justice: A Psychological Analysis. Hillsdale, NJ: Lawrence Erlbaum Associates.

Walton, Richard E. 1985. "From Control to Commitment in the Workplace." Harvard Business Review 63 (2): 77-84.

Wright, Patrick M., Timothy M. Gardner, Lisa M. Moynihan, and Mathew R. Allen. 2005. "The Relationship between HR Practices and Firm Performance: Examining the Causal Order." Personnel Psychology 58: 409-46. 